\title{
Evaluation of compressive strength in geopolymer mortars produced using iron ore tailings ground by tumbling ball mills
}

\author{
Eduardo Júnio D’Almeida Silva ${ }^{1 *}$ \\ Douglas Batista Mazzinghy ${ }^{1}$ (D)
}

\begin{abstract}
The use of Iron Ore Tailings (IOT) as finer aggregates and/or fillers in geopolymer mortars is a possible alternative to use the high amount of solid mining wastes produced nowadays. In this study, exploratory tests were carried out to evaluate different proportions of materials that could produce a geopolymer mortar with high compressive strength. The higher compressive strength was obtained considering $50 \%$ of IOT, $25 \%$ of commercial metakaolin and $25 \%$ of an alkaline solution with 1:3 ratio of commercial sodium hydroxide solution $(\mathrm{NaOH})$ and commercial sodium silicate solution $\left(\mathrm{Na}_{2} \mathrm{SiO}_{3}\right)$. The compressive strength obtained after 3 days of curing in room temperature was $23.5 \mathrm{MPa}$. Then an experiment was carried out to evaluate a possible increase in compressive strength promoted by grinding IOT. The IOT were ground for 1,2 and 3 hours using a tumbling ball mill and the finer IOT were used to produce geopolymer mortars considering the same proportions of materials which higher compressive strength was obtained without grinding IOT. The grinding process for the IOT investigated showed to be not effective, as it gives similar compressive strength results as without grinding.
\end{abstract}

Keywords: Mining wastes; Grinding; Coproducts; Sustainability; Circular economy.

\section{Introduction}

Brazil is the second largest producer of iron ore in the world [1] and, in 2018, the country produced 568.7 million tons of ROM [2]. In addition, according to the Minas Gerais State Environment Foundation (Feam), 562Mt of mining wastes was produced only in the state of Minas Gerais in 2017 , in which $52 \%$ of this amount are tailings [3].

In recent years, Brazil has faced two disastrous failure iron ore tailings dams in Mariana and Brumadinho, both in the state of Minas Gerais, in Brazil. The first one happened on November $5^{\text {th }}, 2015$, when the Fundão tailings dam failed moving 32.6 million cubic meters of tailings [4], affecting several municipalities, especially the closest districts (Bento Rodrigues and Paracatu de Baixo in Mariana and Gesteira in Barra Longa) and reaching the Doce river along 650 kilometers [5]. According to the company, Samarco [4], there were 19 fatal victms. They also assured that many environmental recovery projects have been done, such as the revegetation of 830 hectares in the region (and they intend to extend this, reaching $20 \mathrm{~km}^{2}$ in total), the removal of 170,000 cubic meters of tailings from the urban areas of Barra Longa and farms of Gesteira, and the issue of 71,000 water analysis reports. The second one occurred on January 25 th, 2019 [6], when the dam I of the Córrego do Feijão mine, Vale company, which contained 11.7 million cubic meters of tailings, failed [7]. This affected many municipalities, killing 270 people while 11 are still missing and reaching the Paraopebas river [7]. In addition, the Forestry Institute of the State of Minas Gerais [6] stated that a total area of $2.92 \mathrm{~km} 2$ was taken by the tailings, which represents 1.5 $\mathrm{km} 2$ of vegetation and $2.3 \mathrm{~km} 2$ of the Serra do Rola Moça State Park buffer zone [8].

Therefore, it is necessary to find better ways of dealing with mining wastes. Given this great production of iron ore wastes and that they are mostly composed of silica, their use as finer aggregates and/or fillers in geopolymer mortars can be an alternative use for this material.

\subsection{Geopolymers}

Geopolymers are alkaline activating materials composed of aluminosilicates and have low emissions of $\mathrm{CO}_{2}$ in its production, besides of great compressive strength, resistance to acids and high temperatures [9]. The reaction is usually given by a precursor (aluminosilicate such as metakaolin), activating reagents (sodium hydroxide and sodium silicate) and water.

For Pinto [10], geopolymerization directly involves the alkalination of a mineral with pozzolanic properties and is like the synthesis of organic polymers through condensation and the use of supplementary cementitious materials [10]. Davidovits [11] describes geopolymerization

${ }^{1}$ Departamento de Engenharia de Minas, Universidade Federal de Minas Gerais - UFMG, Belo Horizonte, Brasil.

*Corresponding author: edujdsilva@gmail.com cited. 
as an exothermic reaction that is polycondensation of monomers, assuming that the syntheses are carried out by oligomers (dimers or trimers) that provide the unitary structures of the three-dimensional macromolecules [11]. Geopolymer cements are amorphous inorganic materials, composed of alkalinized aluminosilicates that have lower energy and $\mathrm{CO}_{2}$ consumption when compared to Portland cements [12]. One possible safer and more sustainable use for iron ore tailings is applying them as fines aggregates and/or fillers in geopolymer mortars.

\subsection{Geopolymer mortars using Iron Ore Tailings}

Toffolo et al. [13] studied the use of iron ore dam tailings to produce concrete blocks for paving. These blocks were composed of gravel, cement, sand, additives, water and iron ore tailings. By varying the percentage of iron ore tailings in 10,50 and $80 \%$ in the concrete's composition, they found that the only compressive strength results below $50 \mathrm{MPa}$ (which is the minimum required resistance by the Brazilian Association of Technical Standards, ABNT, for concrete of paving) were the samples with $80 \%$ of iron tailings.

Kuranchie et al. [14] obtained technically satisfactory geopolymer bricks according to American Society for Testing and Materials (ASTM International) and Australian Standards (AS), whose costs were lower than those of burnt commercial clay bricks. They determined optimal parameters: iron ore tailings with particle size distribution below $212 \mu \mathrm{m}$, $31 \%$ sodium silicate solution, initial adjustment time of 15 minutes, curing temperature of $80^{\circ} \mathrm{C}$ and subsequent curing time of 1 day (compressive strength of 19.2 MPa), 3 days (compressive strength of $34.0 \mathrm{MPa}$ ), 7 days (compressive strength of $50.3 \mathrm{MPa}$ ), and 14 and 28 days (compressive strength below $40.0 \mathrm{MPa}$ ). Their compressive strength results are lower for curing times greater than 7 days.

Katti et al. [15] highlight that geopolymers composed of up to $40 \%$ of iron ore tailings show greater compressive strength, reaching a maximum of $48.7 \mathrm{MPa}$ with 28 days of cure, while percentages of 60 to $100 \%$ of tailings obtained inferior results, with a maximum of $46.1 \mathrm{MPa}$ for $60 \%$ and 28 days of cure.

Guimarães et al. [16] found that geopolymer mortars produced with mining tailings may have satisfactory compressive strength values, and the best result was $28 \mathrm{MPa}$ after 7 days of curing with $50 \%$ of iron ore tailings and $50 \%$ of geopolymer binder [16]. Although there is still a need for further studies, good mechanical properties indicate the possible use of mining tailings for geopolymer mortars in civil construction.

Borges et al. [17] concluded that iron ore tailings may be suitable to produce mortar and concrete, but they recommended further studies to carry out long-term durability tests of these materials [17]. For them, geopolymers composed of up to $50 \%$ of iron ore tailings from jig and spiral classification processes are as dense as geopolymers produced with natural quartz aggregate, and, for higher percentages, the former is denser than the latter. Their mean compressive strength results ranged from 36.9 to $44.4 \mathrm{MPa}$ and 36.3 to $49.5 \mathrm{MPa}$ for a solution to binder ratio of 1.2 and 1.3, respectively.

Therefore, previous studies show that the geopolymer mortar obtained adding mining wastes may be a viable option for civil construction as they comply with the minimum compressive strength results determined by the standards. In addition, it is noticed that there is a trend of the longer the curing time, the greater the compressive strength.

The establishment of the compressive strength of Portland cement mortars in Brazil is standardized by ABNT NBR 7215 [18] and their composition are controlled by ABNT NBR 16697 [19], in which the minimum compressive strength for Portland cement mortars composed of pozzolanic material is equal to $25 \mathrm{MPa}$ at the age of 28 days of cure. The study of physical indices, such as water absorption and voids index by immersion and boiling, is an important tool in the characterization of the material produced, which is standardized by ABNT NBR 9778 [19,20]. Therefore, this work seeks the composition of geopolymer mortar, using iron ore tailings, which best fits the Brazilian standards mentioned.

The aim of this study is analyzing the use of iron ore tailings in the development of a geopolymer mortar and studies the influence of the amount of them as aggregates and/ or fillers - and their grinding - in the compressive strength.

\section{Material and methods}

\subsection{Materials}

The following materials were used: commercial metakaolin (MK) as a precursor, an alkaline solution (AS) composed of commercial sodium hydroxide solution (SH) and commercial sodium silicate solution (SS) in the proportion of 1:3 as activators, and iron ore tailings (IOT) as finer aggregates and/or fillers.

\subsection{Characterization}

The chemical compositions of MK, SH and SS were obtained from manufacturers technical specifications. IOT chemical composition was obtained by Philips (PANalytical) X-ray fluorescence (XRF) spectrometer PW 2400 model and mineral phases by X-ray diffraction (XRD) PANalytical $X$ 'Pert APD diffractometer using copper radiation $(\mathrm{CuK} \alpha)$. A laser particle size analyzer CILAS 1190 was used to obtain the particle size distributions for MK and IOT.

\subsection{Exploratory tests}

Exploratory tests with different proportions of materials were carried out as shown in Table 1.

Initially, the MK and the AS were mixed for 10 minutes using a planetary mixer. Then, the IOT were added and the mixture was blended for more 10 minutes. Water was 
added to maintain the consistency/workability of the mortar, seeking a water/solid ratio below 0.35 .

Afterwards, three samples for each test were molded in PVC tubes with a diameter of $3.5 \mathrm{~cm}$ and a height of $7.0 \mathrm{~cm}$. These samples were submitted to compressive strength tests after 3 days of curing at room temperature (about $25^{\circ} \mathrm{C}$ ) using an Engetotus electric press at loading rate of $15.0 \mathrm{kN} / \mathrm{min}$.

\subsection{Grinding IOT}

To evaluate the effect of grinding IOT, geopolymer mortars were produced considering the exploratory test with higher compressive strength obtained. Dry grinding tests were carried out for 1, 2 and 3 hours in a tumbling ball mill with $254 \mathrm{~mm}$ in diameter and $254 \mathrm{~mm}$ in length, according to the parameters indicated in Table 2.

The percentage passing in $38 \mu \mathrm{m}$ was considered as target to evaluate the grinding fines. Finally, compressive strength tests were performed after 3, 7, 14 and 28 days of curing at room temperature (about $25^{\circ} \mathrm{C}$ ).

\section{Results and discussions}

\subsection{Characterization}

The chemical composition of the materials is described in Table 3. IOT chemical composition was obtained by XRF and MK, SS and SH chemical composition was obtained by manufacturers technical specifications.

The mineral phases obtained by X-ray diffraction (XRD) shown that IOT are composed of $88.8 \%$ of quartz, $10.4 \%$ of hematite and $0.7 \%$ of goethite in crystalline phase. Table 4 shows the particle size distribution of the IOT and the MK obtained from laser particle size analyzer.

As MK has finer particles and the minerals are majority in amorphous phase, then it acts as a precursor in the geopolymerization reaction. Consequently, as the IOT have slightly coarser particles and the minerals are in the crystalline phase, they probably do not participate in the geopolymerization reaction. The IOT probably are acting as fine aggregates and/or fillers that guarantees consistency to the geopolymer mortar. Magalhães [21] stated that small particles, like the IOT, improve some physical properties by filling the pores in the cement paste and pozzolans, such as the MK, increase the reactivity of the material by generating a larger surface area [21]. Finally, Table 5 shows the water/ solid ratio used in the tests.

As mentioned, in each test performed the water/ solid ratio of $0.35 \pm 0.02$ was kept constant. This value was adopted based on Patankar et al. [22] studies that showed that the most suitable range for water/solid ratio is 0.25 to 0.35 , as higher ratio gives segregated mix and lower ratio gives viscous and dry mix.
Table 1. Exploratory tests.

\begin{tabular}{cccc}
\hline TEST & IOT & MK & AS \\
\hline 1 & $50 \%$ & $25 \%$ & $25 \%$ \\
2 & $60 \%$ & $20 \%$ & $20 \%$ \\
3 & $70 \%$ & $15 \%$ & $15 \%$ \\
4 & $80 \%$ & $10 \%$ & $10 \%$ \\
\hline
\end{tabular}

Table 2. Ball mill operational conditions.

\begin{tabular}{ccr}
\hline Ball charge & $\mathrm{kg}$ & 12.3 \\
IOT & $\mathrm{kg}$ & 1.9 \\
Balls diameter & $\mathrm{mm}$ & 25.4 \\
Mill speed & $\mathrm{RPM}$ & 75.3 \\
\hline
\end{tabular}

Table 3. Chemical composition of the materials.

\begin{tabular}{cccccc}
\hline Material & $\mathrm{SiO}_{2}(\%)$ & $\begin{array}{c}\mathrm{Al}_{2} \mathbf{O}_{3} \\
(\%)\end{array}$ & $\begin{array}{c}\mathbf{N a}_{2} \mathbf{O} \\
(\%)\end{array}$ & $\mathbf{K}_{2} \mathbf{O}(\%)$ & $\mathbf{H}_{2} \mathbf{O}(\%)$ \\
\hline IOT & 83.0 & 0.3 & - & - & - \\
MK & 60.0 & 32.2 & 0.1 & 1.8 & - \\
SS & 32.6 & - & 14.6 & - & 52.8 \\
SH & - & - & 77.5 & - & 22.5 \\
\hline
\end{tabular}

Table 4. Particle-size distribution of the solids.

\begin{tabular}{cccc}
\hline Material & $\mathbf{D}_{\mathbf{1 0}}(\boldsymbol{\mu m})$ & $\mathbf{D}_{\mathbf{5 0}}(\boldsymbol{\mu m})$ & $\mathbf{D}_{\mathbf{9 0}}(\boldsymbol{\mu m})$ \\
\hline IOT & 22.1 & 84.1 & 168.6 \\
MK & 12.1 & 22.4 & 38.8 \\
\hline
\end{tabular}

Table 5. Water/Solid ratio.

\begin{tabular}{cc}
\hline TEST & WATER/SOLID \\
\hline 1 & 0.37 \\
2 & 0.35 \\
3 & 0.33 \\
4 & 0.34 \\
\hline
\end{tabular}

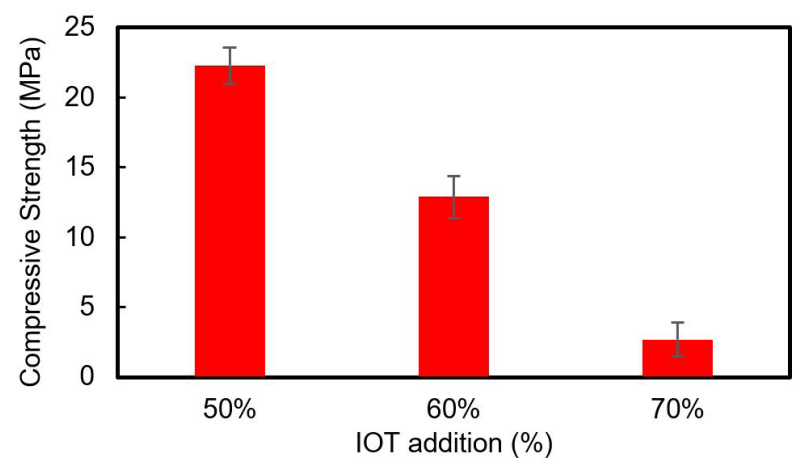

Figure 1. Compressive strength of geopolymer mortars after 3 days of curing with different percentages of IOT added as aggregates and/or fillers.

\subsection{Compressive strength for exploratory tests}

Figure 1. shows the obtained results of compressive strength for exploratory tests after 3 days of curing using different proportions of IOT as aggregates and/or fillers. The mean of the three compressive strength results for each test was considered in Figure 1.

There is a tendency to reduce the efficiency of the geopolymer mortar reaction as the dosage of reagents 


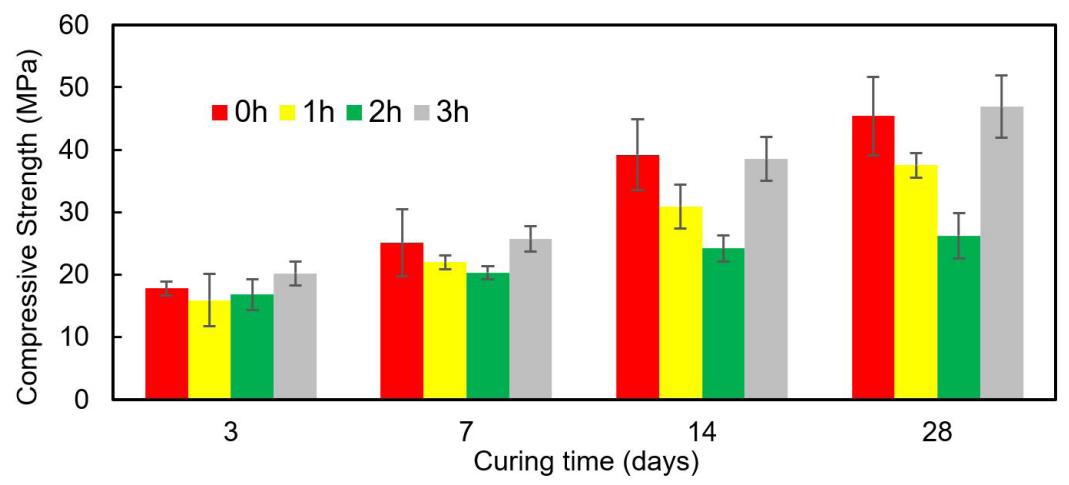

Figure 2. Compressive strength considering different IOT grinding times and 50\% of IOT in the geopolymer mortar.

decreases. Thus, the higher the percentage of IOT, the lower the compressive strength of the geopolymer mortar. Furthermore, it was noticed that, with three days of cure, there was no successful reaction in the exploratory test 4 (Table 1), evidenced by the non-hardening of the samples. This reinforces the Toffolo et al. [13] conclusions on the low effectiveness of geopolymer bricks composed of $80 \%$ of IOT.

\subsection{Compressive strength for ground IOT}

Based on the proportions of materials used in the exploratory test 1 , as its compressive strength results were the higher obtained, grinding tests were performed and the percentage passing in $38 \mu \mathrm{m}$ screen obtained from different grinding times is shown in Table 6 .

Figure 2 shows the effect of the IOT grinding on the compressive strength results, in which a mean value from three samples was considered for each test.

It is considered the standard deviations in the Figure 2 due to samples molding variations and equipment imprecisions. By the results, as the time of cure increases, the compressive strength also increases. All the tests - except with $2 \mathrm{~h}$ - had an increment in their final compressive strength equals to about 2 times their value in the first 3 days of curing. Figueiredo et al. [23] produced geopolymers using solid activators (HS and SS), MK, IOT and water and they obtained $52 \mathrm{MPa}$ with 28 days of cure. Similarly, their initial compressive strength of $25.5 \mathrm{MPa}$ with 1 day of cure raised to approximately its double.

The results indicate that the growth in compressive strength over time obtained by IOT ground by 3 hours and IOT without grinding are similar. This means that the grinding process for the IOT studied is not effective, as it gives similar compressive strength results as without grinding. Grinding involves higher costs, then to justify its use the gain in compressive strength should be considerably. One possible explanation for equivalent results considering and not considering IOT grinding is that the ground IOT are acting as fillers only. In this case, probably additional IOT as aggregates could improve the compressive strength.

Tests carried out with 1 and 2 hours of grinding showed lower compressive strength results when compared with IOT
Table 6. \% passing in $38 \mu \mathrm{m}$ for different grinding times.

\begin{tabular}{cc}
\hline Time (hours) & $\mathbf{0}<\mathbf{3 8} \boldsymbol{\mu m}$ \\
\hline 0 & 21.5 \\
1 & 43.8 \\
2 & 62.1 \\
3 & 68.8 \\
\hline
\end{tabular}

without grinding. This result is unexpected and requires further investigation to understand this behavior. One possible explanation is a material agglomeration during the initial grinding times, so the clustered particles limited the geopolymer reaction. The inferior geopolymer mortar consistency observed - when compared to the other tests - also indicates that the geopolymer reaction may have not happened completely.

Figure 2 also shows that the compressive strength of the geopolymer mortars produced meets the Brazilian standard for Portland cement mortars, in which the minimum compressive strength is $25 \mathrm{MPa}$ in 28 -day-old materials (ABNT NBR 7215 and NBR 16697) [18,19]. Finally, the visual aspect of the samples with IOT ground for 3 hours became clearer and more brittle than the other times. Given the pre-fixed condition of the water/solid ratio of 0.35 , it is inferred that the increase in the surface area of the IOT particles directly influences the need to add water to the mortar.

It is suggested for the next studies the use of the one-part method (or "just add water") by mixing dry precursors and dry reagents and grinding them with the aggregates together. Luukkonen et al. [24] stated that the one-part geopolymer mortars can reach up to $80 \mathrm{MPa}$ values at the age of 28 days, besides of all your advantages beyond the two-parts (use of alkaline solutions), such as not having a viscous solution, being a user-friendly to handle, and being easier and cheaper to transport dry activators [24].

\section{Conclusions}

The proportion of materials directly affects the compressive strength of the geopolymer mortar. Decreasing precursors and activators and increasing IOT results in lower compression strength values. Exploratory tests showed 23.5 MPa for compressive strength after 3 days of curing 
at room temperature considering $50 \%$ IOT, $25 \% \mathrm{MK}, 25 \%$ AS and 0.35 water/solid ratio.

The behavior of the compressive strength for geopolymer mortars with ground IOT at different times follows an expected growth over time. The results indicate that the growth in compressive strength over time obtained by IOT ground by 3 hours and IOT without grinding are similar. Then, the use of IOT without grinding, for the sample tested, is still the best option given the cost of grinding operation. For further studies about the grinding effect in the synthesis of geopolymers, it is important to be very careful when adding the reagents and the IOT, so no agglomeration will be formed and the materials must be completely dry. One possible explanation for equivalent results considering and not considering IOT ground is that the ground IOT are acting as fillers only.
By the satisfactory compressive strength results obtained, geopolymer mortars seem to be a viable alternative for the sustainable use of IOT in the state of Minas Gerais, in Brazil. However, further studies on the physical and chemical characteristics are necessary for the application of this material in civil construction.

For Provis [25], eco-friendly mortars may not replace the Portland cement mortars because of challenging applications, more cautious control of preparation and curing, and restrain of their supply chain, but they are a valuable and cost-effective element for the future of sustainable construction materials. Simultaneously, Scrivener et al. [26] believe that geopolymers are limited in performance and worldwide supplies, even though they can reduce the $\mathrm{CO}_{2}$ emissions.

\section{References}

1 U.S. Geological Survey. Mineral Commodity Summaries. USA: U.S. Geological Survey; 2020 [cited 2020 June 30 ]. p. 88-89. Available at: https://pubs.usgs.gov/periodicals/mcs2020/mcs2020-iron-ore.pdf

2 ANM - Agencia Nacional Brasileira. Anuário Mineral Brasileiro 2019. pp 11. [cited 2019 Sep 2] Available at: https://www.gov.br/anm/pt-br/centrais-de-conteudo/publicacoes/serie-estatisticas-e-economia-mineral/anuariomineral/anuario-mineral-brasileiro/AMB2019_anobase2018_FINAL.pdf . In Portuguese.

3 Fundação Estadual do Meio Ambiente - FEAM. Inventário de Resíduos Sólidos Industriais Ano Base 2017. Belo Horizonte: FEAM; 2018 [cited 2020 Sep 2]. Available at: http://www.feam.br/images/stories/2018/RESIDUOS/ Relat\%C3\%B3rio_Invent\%C3\%A1rio_Industria_2018_ano_base_2017.pdf

4 Samarco. One Year After the Fundão Dam Failure. Brasil: Samarco; 2016 [cited 2020 July 7]. Available at: https:// www.samarco.com/wp-content/uploads/2020/12/Book-Samarco_Ingles_v1-2.pdf

5 Folha de São Paulo. Samarco usa acordo com a união para pedir absolvição de crime ambiental. Brasil: 2017. Available at: https://www1.folha.uol.com.br/cotidiano/2017/10/1929167-samarco-usa-acordo-com-uniao-para-pedirabsolvicao-de-crime-ambiental.shtml

6 Vale. Brumadinho [cited 2020 July 7]. Brasil: Vale; 2020 Available at: http://www.vale.com/esg/pt/Paginas/ Brumadinho.aspx

7 Vale. Vale atualiza informações sobre o rompimento da barragem de Brumadinho. Brasil: Vale; 2019 [cited 2020 July 7]. Available at: http://www.vale.com/brasil/PT/aboutvale/news/Paginas/Vale-atualiza-informacoes-sobre-orompimento-da-barragem-de-Brumadinho.aspx

8 Instituto Estadual de Florestas - IEF. Nota de Esclarecimento 12 - Desastre Barragem B1. Belo Horizonte: IEF; 2019. [cited 2020 July 7]. Available at: http://www.ief.mg.gov.br/noticias/2587-nota-de-esclarecimento-12-desastrebarragem-b1

9 Azevedo AGS, Strecker K, Lombardi CT. Produção de geopolímeros à base de metacaulim e cerâmica vermelha. Cerâmica. 2018;64:388-396. http://dx.doi.org/10.1590/0366-69132018643712420.

10 Pinto AT. Introduction to the study of geopolymers. Vila Real, Portugal: Universidade de Trás-os-Montes e Alto Douro (UTAD); 2006. In Portuguese.

11 Davidovits J. Properties of geopolymer cements. In: Proceedings First International Conference on Alkaline Cements and Concrets, Scientific Research Institute on Binders and Materials; 1994; Kiev, Ukraine. Kiev, Ukraine: Kiev State Technical University; 1994. p. 131-149

12 Davidovits J. Geopolymers: inorganic polymeric new materials. Journal of Thermal Analysis and Calorimetry. 1991;37:1633-1656. http://dx.doi.org/10.1007/BF01912193.

13 Toffolo RVM, Filho JNS, Batista JOS, Silva SN, Cury AA, Peixoto RAF. Technical feasibility of concrete elements for paving produced with iron ore dam tailings. In $56^{\circ}$ Congresso Brasileiro de Concreto - CBC; 2014; São Paulo. São Paulo: IBRACON; 2014. 
14 Kuranchie FA, Shukla SK, Habibi D. Utilisation of iron ore mine tailings for the production of geopolymer bricks. International Journal of Mining, Reclamation and Environment. 2014;30(2):92-114. http://dx.doi.org/10.1080/17480 930.2014.993834.

15 Katti MM, Narayana L, Hasanbadi SHS, Ramshi R. Utilization of iron ore tailings in geopolymer concrete. International Research Journal of Engineering and Technology (IRJET), 2018;5(4):4522-4525. [cited 2020 Sep 2]. Available at: https://www.irjet.net/archives/V5/i4/IRJET-V5I41006.pdf

16 Guimarães ACPD, Oliveira MFM, Silva JP, Lameiras FS. Obtenção de geopolímero com adição de rejeito de mineração depositado na barragem de Candonga (Rio Doce-MG, Brasil). In: CLBMCS $20183^{\circ}$ Congresso LusoBrasileiro Materiais de Construção Sustentáveis; 2018 February 14-16; Coimbra, Portugal. Braga: Universidade do Minho; 2018.

17 Borges PHR, Ramos FCR, Caetano TR, Panzerra TH, Santos H. Reuse of iron ore tailings in the production of geopolymer mortars. REM - International Engineering Journal. 2019;72:4. http://dx.doi.org/10.1590/037044672017720169.

18 Associação Brasileira de Normas Técnicas - ABNT. NBR 7215: Cimento Portland - Determinação da resistência à compressão. Rio de Janeiro: ABNT; 1996. [cited 2020 June 30]. p. 1-8. Available at: http://professor.pucgoias.edu. br/SiteDocente/admin/arquivosUpload/17827/material/NBR\%207215\%20-.pdf

19 Battagin AF. Norma comentada: ABNT NBR 16697 - cimento Portland - requisitos. Mapa da Obra; 2019 [cited 2020 June 30]. Available at: https://www.mapadaobra.com.br/capacitacao/nbr-16697/

20 Associação Brasileira de Normas Técnicas - ABNT. NBR 9778: Argamassa e concreto endurecidos - Determinação da absorção de água, índice de vazios e massa específica. Rio de Janeiro: ABNT; 2009 [cited 2020 June 30]. p. 1-4. Available at: https://www.abntcatalogo.com.br/norma.aspx?ID=52163

21 Magalhães LF. Avaliação do rejeito de minério de ferro como material cimentício suplementar [dissertação de mestrado]. Belo Horizonte: Centro Federal de Educação Tecnológica de Minas Gerais (CEFET-MG); 2018. [cited 2020 Dec 5]. Available at: http://www.posmat.cefetmg.br/wp-content/uploads/sites/120/2018/02/ Disserta\%C3\%A7\%C3\%A3o_Luciano_Fernandes.pdf

22 Patankar SV, Jamkar S, Ghugal M. Effect of water-to-geopolymer binder ratio on the production of fly ash based geopolymer concrete. International Journal of Advanced Technology in Civil Engineering. 2013;2(1):79-83. http:// dx.doi.org/10.13140/2.1.4792.1284.

23 Figueiredo RAM, Coura EC, Mazzinghy DB. Obtaining geopolimeric mortar from iron ore flotation waste. In: Proceedings of the XXVIII National Meeting on Mineral Treatment and Extractive Metallurgy; 2019; Belo Horizonte, MG. Belo Horizonte: UFMG; 2019. In Portuguese.

24 Luukkonen T, Abdollahnejad Z, Yliniemi J, Kinnunen P, Illikainen M. One-part alkali-activated materials: a review. Cement and Concrete Research. 2018;103:21-34. http://dx.doi.org/10.1016/j.cemconres.2017.10.001.

25 Provis JL. Alkali-activated materials. Cement and Concrete Research. 2018;114:40-48. http://dx.doi.org/10.1016/j. cemconres.2017.02.009.

26 Environment UN, Scrivener KL, John VM, Gartner EM. Eco-efficient cements: potential economically viable solutions for a low- $\mathrm{CO}_{2}$ cement-based materials industry. Cement and Concrete Research. 2018;114:2-26. http:// dx.doi.org/10.1016/j.cemconres.2018.03.015.

Received: 13 Sep. 2020

Accepted: 5 Jan. 2021 